\title{
ARTIGO
}

$\frac{\text { dOI htps://doi.org/10.22481/praxisedu.v16i37.6158 }}{\text { d. }}$

\section{MODELLING THEORY OF MIND, DIVERGENT THINKING AND MATHEMATICAL PROBLEM POSING OF FIRST GRADERS}

\author{
TEORIA DA MODELAGEM DA MENTE, PENSAMENTO DIVERGENTE E \\ POSICIONAMENTO DE PROBLEMAS MATEMÁTICOS DE ALUNOS DO PRIMEIRO \\ ANO
}

\author{
TEORÍA DE MODELADO DE LA MENTE, PENSAMIENTO DIVERGENTE Y \\ PLANTEAMIENTO DE PROBLEMAS MATEMÁTICOS DE PRIMER GRADO
}

\author{
Malihe Jami \\ Islamic Azad University - Iran \\ Elahe Aminifar \\ Shahid Rajaei Teacher Training University - Iran \\ Abolfazl Tehranian \\ Islamic Azad University - Iran \\ Ahmad Shahvarani Semnani \\ Islamic Azad University - Iran \\ Mohammad Hassan Behzadi \\ Islamic Azad University - Iran
}

\begin{abstract}
Purpose: Problem posing has a central importance in the discipline of mathematics and in the nature of mathematical thinking. The purpose of this study was to investigate the explanatory and predictive relationships among the variables of the theory of mind, divergent thinking, and problem posing in the first grade students of elementary school, using structural equation modeling approach. Method: The subjects are 345 students (176 girls and 169 boys) of the first graders of elementary school of Zahedan, using available sampling model. They lived and were educated in the average, urban areas of the city. Students responded to the theory of mind, divergent thinking, and mathematical problem posing tests. Structural Equation Modeling was used to analyze the data gathered survey instrument. Findings: The data analysis revealed a significant $(\mathrm{P}<0.05)$ impact of divergent thinking variable on the outcome of problem posing skills. Interestingly, an indirect impact of theory of mind variable via divergent thinking on the problem posing variable were observed in this study. These findings clearly demonstrated the positive impacts of the components of divergent thinking and theory of mind on the mathematical problem posing. Implications for Research and Practice: remains necessary to further explore the role of mind on the problem posing ability with regard to mathematical education.
\end{abstract}

Keywords: Mathematical education; Problem posing; Divergent thinking; Theory of mind. 
Resumen: Propósito: La presentación de problemas tiene una importancia central en la disciplina de las matemáticas y en la naturaleza del pensamiento matemático. El propósito de este estudio fue investigar las relaciones explicativas y predictivas entre las variables de la teoría de la mente, el pensamiento divergente y la presentación de problemas en los estudiantes de primer grado de la escuela primaria, utilizando el enfoque de modelado de ecuaciones estructurales. Método: Los sujetos son 345 estudiantes (176 niñas y 169 niños) de los alumnos de primer grado de la escuela primaria de Zahedan, utilizando el modelo de muestreo disponible. Vivieron y fueron educados en las áreas urbanas promedio de la ciudad. Los estudiantes respondieron a la teoría de la mente, el pensamiento divergente y las pruebas de planteamiento de problemas matemáticos. El modelado de ecuaciones estructurales se utilizó para analizar los datos recopilados en el instrumento de encuesta.

Resultados: El análisis de datos reveló un impacto significativo $(\mathrm{P}<0.05)$ de la variable de pensamiento divergente en el resultado de las habilidades para plantear problemas. Curiosamente, en este estudio se observó un impacto indirecto de la variable de la teoría de la mente a través del pensamiento divergente sobre la variable de planteamiento del problema. Estos hallazgos demostraron claramente los impactos positivos de los componentes del pensamiento divergente y la teoría de la mente sobre el problema matemático que plantea.

Implicaciones para la investigación y la práctica: sigue siendo necesario explorar más a fondo el papel de la mente en la capacidad de plantear problemas con respecto a la educación matemática.

Palabras clave: Educación matemática; Planteamiento de problemas; Pensamiento divergente; Teoría de la mente.

Resumo: Objetivo: A colocação de problemas tem uma importância central na disciplina de matemática e na natureza do pensamento matemático. O objetivo deste estudo foi investigar as relações explicativas e preditivas entre as variáveis da teoria da mente, pensamento divergente e problema que se apresentam nos alunos da primeira série do ensino fundamental, utilizando a abordagem de modelagem de equações estruturais. Método: Os sujeitos são 345 alunos (176 meninas e 169 meninos) da primeira série da escola primária de Zahedan, usando o modelo de amostragem disponível. Eles viviam e eram educados nas áreas urbanas médias da cidade. Os alunos responderam à teoria da mente, pensamento divergente $\mathrm{e}$ problemas matemáticos que colocam testes. A modelagem de equações estruturais foi utilizada para analisar os dados coletados no instrumento de pesquisa. Resultados: A análise dos dados revelou um impacto significativo $(\mathrm{P}<0,05)$ da variável de pensamento divergente no resultado das habilidades de colocação de problemas. Curiosamente, um impacto indireto da variável teoria da mente, via pensamento divergente, sobre a variável que coloca o problema foi observado neste estudo. Essas descobertas demonstraram claramente os impactos positivos dos componentes do pensamento e da teoria da mente divergentes sobre o problema matemático.

Implicações para pesquisa e prática: continua a ser necessário explorar ainda mais o papel da mente no problema que coloca a capacidade em relação à educação matemática.

Palavras-chave: Educação matemática; Resolução de problemas; Pensamento divergente; Teoria da mente.

\section{INTRODUCTION}

Professionalism plays an important role in everybody's life. The action of the personality at the place and time of professionalism is called as the professional development subject's activity. Professional development - is the longest period of human life. 
(Approximately during the 35-40 years). The transformation of professional life plans, reestablishment of the structure of personality, the leading type of the activity and the modification of social situation is happening during this period. Professional preparation stage has special important during the youth and student years. The concept of the profession is included during the student years and necessary profession qualities starts forming. The student identity is developing both in the way of getting certain qualities and in the professional background.

It should be considered that the youth period has extraordinary importance in student's development. The final of this stage is in solidarity with formed integrity of the behavior, internal unity, and understanding of mutual relations, social normatives and group attempts. Except of the psychological conflicts actualizes the development of personality in student years, it could be focused on the social-pedagogical issues that allows to the solution of the future personal development.

Research shows that in many cases, graduates coming to certain specialty and professional fields cannot ascertain themselves or they approach that field only as "obtaining diploma", and this, in itself, has an obstruction for finding themselves in the field they want and for self-attitude. Facts show that the beginning of this process just comes from the age of adolescent. Formation of interest for certain profession, but its non - confirmation with potential opportunities creates condition for the emergence of the above-mentioned issues. Along with this, the formation of professional choice in an adequate direction in the period of teen years leads to their finding themselves in the professional field they want and realization of their potential in this field, in the end, living a happy lifestyle. In addition, achievement gained in the economic and political life of our country requires from new generation to sign serious successes in the professional field and just thanks to it, it is possible to maintain sustainable development and raise the wellbeing of people. (Rashid Jabbarov.et.al,2019).

Though the professional elements at students begin with the choice of profession, really the strengthening of interest to this profession and the process of becoming professional start in the entering specialty. Our main purpose in this article is determining the development directions of professional qualities on courses, and finding out the conflicts in this process. Because in many cases students don't like the profession they study and transfer to another profession later. This is the waste of time and financial expense. The increasing dynamics of such tendencies shows itself in modern period. And this actualizes the problem. 


\section{DEVELOPMENT}

The professional development directions of personality are investigating in psychology. T.V.Kudrayavtsev classifies the professional development problem of personality, some directions according to the criterias of his choice to the attitude on himself and implementation level of the performance. In his opinion, these directions are following:

1) The creation and forming stage of the professional purposes.

2) Professional training and preparation to the professional activity

3) Mastering to the profession, adaptation, active mastering of professional activity and self-knowledge in the collective

4) Realization of personality in professional atmosphere.[ Kudrayavtsev T.V. 1981]

E.A. Klimov selects the preparation to the conscious choice of the direction, professional preparation stage (15-23 ages)- mastering the knowledge skills and habits of professional activity of future, the development stage of the specialist( from 16-23 to the pension age)- entering the interpersonal professional attitude system and future development levels of the subject of activity. [Klimov E.A., 1996] A.K. Markova chose the professional level of the personality as the selection criteries for the determining of professional development phase. . He makes out 5 levels and 9 stages.

- Pre-professionalism phase - first acquaintance with the specialty

- Three stages of development are included to the professionalism: adaptation, selfactualization, and free learning of the specialty in profession form.

-Super professionalism includes 3 forms of developments: free learning of the specialty, mastering the specialty, creative self-design

- Non-professionalism, performing the work on falsified norms, restoring the deformation of the personality.

- The period after the professionalism-ending of the professional activity.

A short analysis of the student's professional development phase can be concluded that the author' criteria and the basis of the differentiation of this process and nearly identical phases are identified. From the listed above we consider one of the professional development-the stage of professional preparation-without central stage. This is because at this stage social situation is characterized by the politics and civic perfection, social independence, the new system of mutual relationship of new role of the personality at the collective. 
A.V. Dmitriev and V.T. Lisovski, as a social group, identifies the following standard features of studenthood.

- Understanding of a prestigious social status of a student and understanding of the training at high school the a progress phase on education stage as a in the development of future careers;

- content, intensity of mutual interaction, as a condition of socialization communication, building and strengthening relationships with other social groups and institutions;

- an intensive search for meaning of life, a tendency to new ideas, innovation, progressive public education [V.T. Lisovski, andA.V. Dmitriev, 1974].

- As I.S Kon shows, entering the independent life in society, the beginning of a particular individual biography, is not smooth and without contradictions.

Researchers believe that the main psychological contradiction of youth is the conflict between the specification and formation of actualized students of the improvement of the identification mechanism [Cohn, 1975].

V.V. According to Stalin, the origin of the youth is the formation of personal identity as an important psychological process [Stolin, VV, 1983]. Understanding the motives of his behaviour, intimation of personal life, and behaviour is a fundamental self-reflection in adolescence. the uniqueness of himself/ is the fundamental manifestation of self expression in adolescence

V.S. According to Mukhina, the dialectically related but coherent identification and specification mechanisms of individualization, for their deep existence, precisely define the identity of the individual in his youth.

Through a difficult path of ontogenetic identification with other people, the young man, girl, master the socially important features of the personality, and internalize the social experience. Through a difficult path of ontogenetic identification with other people, the young man, girl, master the socially important features of the personality, and internalize the social experience. In youth, the identification mechanism allows them to feel in the position of other people and to experience the same emotion as theirs. However at young age the requirement for specification and cooperation is actualized, it is important to protect the intrusive interventions of his inner world in order to realize its claims with confession of protecting one's individuality and strengthening the emotions of the personality. V.S.,1999]. 
The central idea of the progressive stages of the introduced subjectivity is the individualization of social norms, values, and ideals through the formation of one's own position. By overcoming the pressure of position, professional, political, or confessional determination of the time, the young man is quickly formed, unknowingly, and is responsible for his particular independence.

M.S.Yanitski notes in his research that "formal conditions of student work require incredible unpredictability to achieve the intended result, so adaptation of these changes can be practically consistent with the continuously changing curriculum and curriculum in higher education [Yanitski MS.]

According to Madorskaya, the majority of students (especially I and II courses) experience a complex set of destructive conditioned difficulties (social, psychological, social, psychological and domestic) in the process of teaching adaptation at high school, to the emotional negative state .[Madorskaya SM, 1986].

In his research, D.V. Kolesov focuses on accentuating the problems that arise with changing the boundaries of independence that are higher at students than pupils. [Kolesov DV, 1980]. According to the information of author, the exam session causes high stressogenicity at students. The facts are intriguing: if poor learning students experience stress due to unpredictability during exams, it is typical students to develop the state of stress related to the intellectual pressure for well-performing.

In his research, R.R. Blajis shows psychological discomfort situation of students primarily manifested in cognitive, emotional, and behavioural environments. Analyzing the experimental informations, R. Blajis identifies the following factors of psychological discomfort situation of students the factor of eccentricism; passive dissatisfaction factor; excitement factor, factor of external dependence [Blajis R.R., 1987]. The author defines that the causes of psychological discomfort situation can be attributed to the existence of such interrelated conditions: personal characteristics related to upbringing and development, the overall activity level of personality.

A. Groysman investigates the didactogenic problems at high schools and touches on interpersonal conflict. According to the author, these contradictions are the basis of their psychological disadaptation. He examines different aspects of student life and divides them into two groups of disadaptation. The first, the didactogenic group, is related to the stress situation in the learning process (examinations and exam practices.).In combination with such personality characteristics as shyness, typological indecisiveness, worried anxiety, or 
dishonesty and stressful situations such as confusion, frustration, disorientation, anxiety, and tension arise. The second disadaptation group deals with the subject of sexuality in familymarriage (dysfunctional parent family, sexual role conflict, lacks of family upbringing, psychological difficulties in establishing particular family, etc.) Therefore, the author demonstrates significant indicators of violations at the interpersonal relationships system of students in the study group (38.4\%) and in the family sphere (20.6\%) [Groysman AA, 1988].

Investigation of interpersonal conflicts in the value field of students in the teaching process of high school was implemented by Dubçak [Dubçak Q.M, 2000].

According to the information obtained, conflicts arise between the importance of such vital values as material guidance, special health and family life. Researchers also assume that there is a conflict between "I am real" and "I - ideal" as an indicator of interpersonal conflicts of students. By developing and preparing a program of professional development of future psychologists, we conclude that at the early stages of professionalism, identifying two groups of young professionals' components of the "I" concept - structure (whole, leading form of relationship, conformity, breadth) and content - psychological (subject-object affiliation), recognizing and refusing to accept himself as a professional group) promotes their transformation at various stages of specialization.

Let's look at the controversies that promote interpersonal conflicts at different stages of the training at high schools. When entering high schools, it is often found that High school does not give him ready-made "recipes" and algorithms for implementation of future professional activities. To some extent, the inability to form an algorithm for future professional activities is stipulated with the characteristic of education process and its practical orientation. The student begins to realize the ineffectiveness and the idealization of the imaginations with the motives of the future career choice. Apparently, appeared fears and anxieties about their future motivated them to choose the future profession, which is a dissonance of acquired knowledge. The abovementioned events coincide with the normative crises of professional development typical for the student years aggravates the flow of contradictions. During the professional preparation, there is a crisis of professional choice that is clearly manifested in the first and second course of the training. The current crisis is characterized by reduced interest and motivation for education, dissatisfaction with the individual subjects of education, doubts about the correctness of the choice of profession. Sometimes, this crisis can overcome the destructive educational motivation without changing social-professionalism. 


\section{Research aim}

Although the impact of students' professional preparation on the teaching process depends on a variety of factors, it is primarily characterized by student self-esteem and genderbased behaviour

\section{Research Methods}

In the study, the method of finding the quantitative coefficient of self-evaluation was used by SA Budassin. The study was attended by 250 people, including 120 boys and 130 girls. The results obtained were processed by the SSPS program, and the change on the gender differences and courses were the main criterion.

\section{Discussion}

Our research has shown that the requirements for cardinal dynamic changes in I-IV courses and interpersonal relationships are dependent on the level of self-esteem. Compared to I course and III course, it has been found that students have an advantage of adequate assessment that socially appreciated. This means that, as the courses change, students will be able to objectively evaluate their characteristics and to associate them with the personal and psychological qualities of the situational communication partner, to choose the appropriate style of interpersonal relationships, to form the qualities necessary for vocational training and, if necessary, the opportunities to correct the deficiencies are rising.

It should be noted that in the fourth year, in young students with feminist gender role characterises confirming the personality orientation and joining the interpersonal relationships suggested by communication partner, as well as low self-assessment with poor manifestation of vocational training amid certain psychological tension related to the internal contradictory is prevails by.

Statistical differences on the Student's t- criterion is identified on indicators "adequate self assessment of I-IV course respondents with all types of gender identity, exception of the young with the feminine gender role characteristics. $(t=2,43, P=0,95)$. 
Table 1. Indicators of evaluation interpersonal conflict

\begin{tabular}{|c|c|c|c|c|c|c|c|c|c|c|}
\hline \multirow{3}{*}{$\begin{array}{c}\text { Gender } \\
\text { type, } \\
\text { course }\end{array}$} & \multicolumn{10}{|c|}{ Self assessment level } \\
\hline & \multicolumn{2}{|c|}{ MNE } & \multicolumn{2}{|c|}{ PA } & \multicolumn{2}{|c|}{$\mathrm{SE}(\mathrm{d})$} & \multicolumn{2}{|c|}{ SI } & \multicolumn{2}{|c|}{$\mathrm{SH}$} \\
\hline & Person & $\%$ & person & $\%$ & person & $\%$ & person & $\%$ & person & $\%$ \\
\hline \multicolumn{11}{|l|}{ first } \\
\hline $\mathrm{M}$ & - & - & 2 & 33 & 2 & 33 & 1 & 16.7 & 1 & 16,7 \\
\hline MF & - & - & 2 & 50 & - & - & 1 & 25 & 1 & 25 \\
\hline MA & - & - & 1 & 25 & 3 & 75 & 1 & 25 & - & - \\
\hline $\mathrm{F}$ & 2 & 18 & 3 & 27 & 3 & 27 & 2 & 18 & 1 & 9 \\
\hline FM & - & - & 2 & 66,7 & - & - & 1 & 33,3 & - & - \\
\hline FA & - & - & - & - & 1 & 100 & - & - & - & - \\
\hline \multicolumn{11}{|l|}{ third } \\
\hline M & - & - & 1 & 16,7 & 3 & 50 & 1 & 16,7 & 1 & 16,7 \\
\hline $\mathrm{MF}$ & - & - & 2 & 83,3 & - & - & - & - & 1 & 16,7 \\
\hline $\mathrm{MF}$ & - & - & 1 & 16,7 & 3 & 50 & 2 & 33,3 & - & - \\
\hline $\mathrm{F}$ & - & - & 1 & 25 & 2 & 50 & 1 & 25 & - & - \\
\hline FM & - & - & 2 & 33,3 & 3 & 50 & 1 & 16,7 & - & - \\
\hline FA & - & - & - & - & 4 & 80 & 1 & 20 & - & - \\
\hline \multicolumn{11}{|l|}{ Fourth } \\
\hline $\mathrm{M}$ & - & - & 2 & 28,6 & 3 & 42,8 & 1 & 14,3 & 1 & 14,3 \\
\hline $\mathrm{MF}$ & - & - & 2 & 100 & - & - & - & - & - & - \\
\hline MA & - & - & 1 & 16,7 & 3 & 50 & 2 & 33,3 & - & - \\
\hline$F$ & - & - & 1 & 25 & 2 & 50 & 1 & 25 & - & - \\
\hline FM & - & - & 2 & 33,3 & 3 & 50 & 1 & 16,7 & - & - \\
\hline FA & - & - & - & - & 4 & 80 & 1 & 20 & - & - \\
\hline
\end{tabular}

Note: MNE - Neurotic Self-esteem Reduced: PA - Low Self-esteem; SA(d) - self-esteem is adequate; SI - high self-esteem; SH - Self-esteem is higher in neurotic species

As can be seen from Table1, the interpersonal contradictions of inadequate selfassessment (between "I want" and "I can") are expressed in the vast majority of first-year students of gender identity. In the process of interpersonal interactions of individual reflexes in III and IV courses, are adequately aligned with gender identity of the enhanced 
professionalism and self-esteem level, complying with real opportunities and different types of gender identity, becomes adequate adapting with personal characteristics of the respondents. Self-assessment, lower the price of actions, deficiencies, self-dignity and intensifying of interpersonal contractions described in inclination to raise is determined with characteristics of feminine gender-role in young students.

It was found that there were no significant qualitative differences in the nature of role and moral contradictions between I III IV courses according to $t$-criterias of the Student. $(\mathrm{t}=$ $0,131, p=0,95)$. This fact generally shows that there are no significant changes in the nature of interpersonal role conflicts in different courses. At the same time, if the information is focused in the quality differences of role contradictions in learning process in high school, then the following choices can be made. The fourth course highlights the tradition of confrontation of the role position of "I am a student" and "I am a moral person" in IV course. Therefore, ethical norms and behavioural rules led by man, the essence of the moral qualities that reflects internal and moral qualities are confronted with their idealised standards. The moral rules, peculiar break-up take away from the main role position. In the IV course of conflicting tradition for the role position of I am an ideal, I am a student makes signs of globalism. This is typical for most of the respondents, regardless of the courses. This contradiction is predictive and reflects the demand and preparation of senior students to gain new professional positions and roles. Confirmation of this position can be found in the line of works on the psychology of professional activity.

Table 2. Motivational choices of teaching activity of respondents that prevailing interpersonal controversial and different kinds of gender identity.

\begin{tabular}{|l|l|l|l|l|l|l|}
\hline \multirow{2}{*}{ List of the motives } & \multicolumn{7}{|c|}{ Type of Gender identity } \\
\cline { 2 - 9 } & M & MF & MF & M & MA & MA \\
\hline Being a high specialized expert & 14 & 3 & 10 & 10 & 8 & 13 \\
\hline Getting a diploma & 6 & 4 & 7 & 16 & 4 & 9 \\
\hline Continuing the training successfully & 7 & 6 & 6 & 3 & 4 & 3 \\
\hline Learning succesfully and passing exams well & 4 & 7 & 8 & 12 & 9 & 5 \\
\hline Receiving permament scholaship & 7 & 4 & 9 & 3 & 10 & 9 \\
\hline Achieving deep knowledge & 9 & 4 & 14 & 9 & 6 & 9 \\
\hline
\end{tabular}




\begin{tabular}{|l|l|l|l|l|l|l|}
\hline Always being ready for trainings & 3 & 3 & 2 & 3 & 4 & 2 \\
\hline $\begin{array}{l}\text { Not passing of the mastering of subjects during } \\
\text { the training period }\end{array}$ & 4 & 7 & 13 & 7 & 8 & 10 \\
\hline Keeping up with course mates & 1 & 3 & 2 & 2 & 2 & 2 \\
\hline $\begin{array}{l}\text { Future requirements to ensure the success of the } \\
\text { specialty }\end{array}$ & 13 & 4 & 8 & 9 & 9 & 12 \\
\hline Fulfillment of pedagogical requirements & 2 & 8 & 2 & 2 & 4 & 6 \\
\hline Gaining the respect of the teacher & 4 & 7 & 8 & 8 & 3 & 12 \\
\hline Being an example for course & 6 & 1 & 5 & 2 & 2 & 8 \\
\hline Being approved by parents & 6 & 6 & 7 & 9 & 5 & 9 \\
\hline Avoid penalties and charges of bad training & 2 & 7 & 2 & 2 & 6 & 4 \\
\hline Gaining intelectual approval & & & & & & \\
\hline
\end{tabular}

Comparing the motives of training activity with characteristic interpersonal conflicts for respondents and groups identified on gender differences. We should note that we haven't aimed to determine the cause-result relationships in mutual relationships of interpersonal conflicts with the motives of training activity. Because we've tried to find the ideal standards and the conflicts emerging in the profession preparation process at students.

For male respondents in the background of gender differences, these are the top motives for educational activities according to the group protocol. "Become a highly skilled specialist" (73.7\%); "Acquiring deep and quality knowledge" (47, 4\%); "Ensuring the success of future professional activities" (68.4\%); "Gaining intellectual satisfaction" (57.9\%). It can be concluded that the knowledge and status motives of educational activities are balanced in this choice of respondents.

In the background of gender differences, the dominant motives of educational activity for female respondents are: "Becoming a highly skilled specialist" (52.6\%), "Obtaining a diploma" (84.2\%); "Successfully study, passing exams "well "and" excellent "(63.1\%); "Acquiring deep and quality knowledge" (47.4\%); "Intellectual Satisfaction" (47.4\%); The motivational orientation is observed to acquire the status and knowledge advantages here. These motives are related to the quality specifications and the superiority of interpersonal conflicts 
which are inherent to this kind of gender identity. (adaptation of biological gender and gender role characteristics).

Consequently, the conflict of unrealistic desire is enhanced in this group from the point of view of a particular material security, constant intellectual search orientation, subjective job search. Roll and moral conflicts are largely associated with the realization of social roles. The following teaching motives are preferred for a young male respondents with feminine gender role identity: "Reading exams successfully" are "good" and " excellent "(77.8\%); "Don't give up the learning of subjects of teaching period"(77.8\%) "Fulfilling the pedagogical requirements ”(88.9\%),“ Gaining Respect of teachers ”(77, 8\%),“ Avoid penalties and slanders for poor quality training "(77.8\%).

We believe that these motives can be combined with an adaptive approach, which involves adapting to environmental conditions - high school education and interpersonal interaction with important people. The following educational motives prevail in the selection of girls with masculine gender role identity: "Becoming a highly skilled specialist" (72.7\%); "Successfully study, passing exams" good "and" excellent "(81.8\%); "Getting a Permanent scholarship" (90.9\%), "Do not give up studying the subjects of the teaching period" (72.7\%); "Ensuring success of future professional activities" (81.8\%); "Getting Intelligent Consent, Satisfaction" (63.6\%). As with selection of young boys with feminine gender role characteristics, these motives can be combined with the notion of "adaptation", as well as the concept of orientation of environmental adaptation.

The identified motivations for teaching activities are related to the qualitative characteristics of the interpersonal conflicts of these groups of respondents. Thus, the conflict of unrealistic desires is manifested in the characteristics of "love, physical and spiritual flow to any person", "self-esteem, inner harmony, freedom from conflict and doubts." Inadequate selfesteem is expressed as a tendency to reduce or increase the value of deficiencies, self-dignity. (comparison: studying successfully, fulfilling motives of pedagogical requirements)

The identified coherence of interpersonal conflicts across different types of respondents in the context of educational motives and gender differences allows us to conclude and to make assumptions that require further empirical validation. The motives of teaching activities become more thoughtful and balanced. Balance of teaching motives is an important characteristic that enables us to make choices about its stability and work as a common system. 


\section{CONCLUSIONS}

Our research has shown that students' vocational training in the frame of traditional education is influenced by a number of factors, including complex gender role stereotypes. Teachers explain the success and failure of students in various ways.

The failure of girls is explained by lack of skills, and the failure of young boys is due to hard work or inattentiveness, lack of patience. Since childhood, girls are orientated to interpersonal relationships and to other people, thus developing a high sense of expectation and self-esteem by others, especially those of the referent. Highly socially adapted girls are encouraged to adapt to the motivated behavioral model, either directly or indirectly, by the educator. The most typical for girls are situations where they do not rush to show their abilities and liked attentively in a new, non-standard situation group. Thus, the educational institution, as one of the main institutions of gender socialization that has been actively creating gender stereotypes that have been complicated for centuries, can lead to a student's negative roleplaying identity, the confrontation of personality with the substructures (as "I " "I"am an individual member of a professional group). These facts must be taken into account.

\section{REFERENCES}

1. Jabbarov R.V. Ibrahimova, X.N, Valiyeva, YA. (2019). Directions of selfdetermination and professional choice in adolescents in modern times. DILEMAS CONTEMPORANEOS-EDUCACION POLITICA Y VALORES .Vol. 6, Issue

2. Blazis P.P. (1987). Analysis of the state of mental discomfort in students dis .... cand. psychol. sciences. Leningrad, $182 \mathrm{p}$.

3. Geymans G. (1971). Psychology of a woman. SPb., 248 p.

4. Groysman AA (1988). Psychotherapeutic methods in the system of prophylaxis of neurotic disorders in students: Dis. ... Dr. honey. Science. L.,

5. Dubchak G.M. (2000). Intrapersonal conflicts of students during their studies at the university: Abstract. dis. ... cand. psychol. Sciences: Chernivtsi, 19 p.

6. Klimov E.A. (1996). Psychology of professional self-determination. M., 512s. 
7. Kon I.S. (1975). Sexual differences and differentiation of social roles. In the book: Correlation of biological and social in a human being / Materials for a symposium in Moscow. M .: Enlightenment, p. 46

8. Kondratiev M.Yu. (1987). Management of the teaching staff. In the book .; Social Psychology: A manual for pedagogical universities. M .: Progress, p. 48

9. Kolesov D.V. (1980). Conversations about sex education. M .: Pedagogy, $102 \mathrm{p}$.

10. Kudryavtsev T.V. (1981). Psychological and pedagogical problems of higher education // Questions of Psychology, No. 2, p. 20-30

11. Lisovsky V.T., Dmitriev A.V. (1974). Student personality L.: Leningrad State University Publishing House, 184 p.

12. Markova AK (1996). Psychology of professionalism. M.: Education. 308 p.

13. Mukhina B.C. (1999). Phenomenology of the development and existence of personality. M., - V oronezh, 344 p.

14. Madorskaya S.M. (1986). The problem of social adaptation of students to the educational process: Dis. ... cand. philosopher, sciences. Minsk, $239 \mathrm{p}$

15. Stolin V.V. (1983). Self-identity. M .: Moscow Publishing House. university, 585 p.

16. Yanitsky M.S. (1995). The main psychological mechanisms for the adaptation of students to educational activities: Dis. ... cand. psychol. sciences. Kemerovo, 180 p.

\section{SBRE OS AUTORES:}

\section{Malihe Jami}

Department of Mathematics, Science and Research Branch, Islamic Azad University, Tehran, Iran. E-mail: jami.msc@gmail.com

iD http://orcid.otg/0000-0002-7996-4456

\section{Elahe Aminifar}

Department of Mathematics, Faculty of Science, Shahid Rajaei Teacher Training University, Tehran, Iran. Corresponding author: elaheaminifar@srttu.Edu

(iD http://orcid.otg/0000-0002-0316-5789

\section{Abolfazl Tehranian}

Department of Mathematics, Science and Research Branch, Islamic Azad University, Tehran, Iran.E-mail:tehranian@srbiau.ac.ir iD http://orcid.otg/0000-0002-6151-9637 


\section{Ahmad Shahvarani Semnani}

Department of Mathematics, Science and Research Branch, Islamic Azad University, Tehran, Iran. E-mail: maths_ahmad@yahoo.com

(iD http://orcid.otg/0000-0002-6394-2068

\section{Mohammad Hassan Behzadi}

Department of Statistics, Science and Research Branch, Islamic Azad University, Tehran, Iran. E-mail: behzadi.Stat@gmail.com

(iD http://orcid.otg/0000-0002-1849-5588

Recebido em: 24 de outubro de 2019 Aprovado em: 17 de novembro de 2019

Publicado em: 20 de janeiro de 2020 